\title{
Forging a New Nation: A Study of a Portrait of the Artist as a Young Man by James Joyce
}

\author{
Dr. Milon Franz \\ Associate Professor in English, St. Xavier's College for Women, Aluva, Kerala, India
}

\begin{abstract}
The paper tries to contextualize the modernist text, A Portrait of the Artist as a Young Man by James Joyce in the trajectory of nationalism and attempts to posit it as a cultural text that foregrounds the forging of the 'uncreated'. The paper shows how Joyce becomes critical of the nationalization of the past that the Celtic Revival aimed at. The protagonist, Stephen tries to participate in the burgeoning national culture by forging new paths to future. Joyce also criticizes the ethnocentric, xenophobic and monolithic aspects of Irish nationalism which was hostile to the pluralistic, heterogeneous and multivalent perspectives. Along with nationalism, Joyce also criticizes the modern construct of the nation state. Based on the link between nation and imagination, Joyce provides a new possibility of imagining a nation that celebrates the multiple voices by accommodating the marginalized and silenced voices, quite outside the grids of the nation state. The text shows how through the recreation of primordial and perennial cultural and ethnic propensity of Ireland, such a nation can be forged, and thus the reality of experience can be encountered.
\end{abstract}

Keywords: postcolonialism, nationalist historiography, monolithic nationalism, essentialism, homogeneity

\section{Introduction}

A Portrait of the Artist as a Young Man by James Joyce is a cultural text that provides new possibilities of reading in the discursive contexts of the modern / national historiography. This canonical modernist text can be seen as the objectification of a political and cultural crisis, initiated by the hegemonic agencies of colonialism, propelled through the processes of modernization and nationalist risings and augmented by the cross fertilization and eventual hybridization of the postcolonial context. The protagonist of the novel, Stephen depicts the in-between unbelongingness / double consciousness of a colonized and at the same time he struggles against the chauvinistic and monologic perspective of nationalism. The journey of this intensely sensitive and conscientious protagonist to the depths of his subjective ambience unravels his ethnic, cultural and political issues and thereby identifies and records the cultural and political historiography of his race. Posited in the context of the cultural crises experienced by one of the former colonies of Great Britain, the text tries to forge with the help of modernist techniques "the uncreated conscience of race" outside the boundaries of a monolithic, national consciousness and a coherent national identity. While critiquing the monolithic perspective of nationalism, the text also highlights the heterogeneous and polyphonic perspectives in which the marginalized voice is also accommodated. It also questions the myth of the modern nation state in which the struggle between individuality and collectivity ends up in homogeneity.

\section{Irish Nationalism and Joyce}

James Joyce lived in the times of the surging up of Irish nationalism led by writers like W.B.Yeats, Lady Gregory, A. E. Russell, Edward Martyn and Edward Plunkett. But while Yeats and his group tried to revive the Irish past, Joyce was critical of it as he believed in Frantz Fanon's line that it is the responsibility of the native intellectual to forge and to follow the new paths to future and hence to participate in the burgeoning national culture, rather than retrace the steps back to an ossified and inert past which takes him away from the dynamism of the people's struggle. He believed in participating in the reinterpretation of traditional culture in the present with the aim of opening up the possibility of a new future. Rather than extracting from the past what is perceived to be the most valuable and timeless cultural treasures, the native intellectual must learn from the people to modify, reinterpret and reform traditional culture at the service of forging a new national consciousness which places the struggle of the people at its heart. Even though the much acclaimed literary revival was a peasant movement, Joyce found in it an attempt to make the present a rehearsal of the past. In $A$ Portrait and Ulysses, Joyce makes an attempt to flee from the fancy-dress version of tradition as he is against the idea of Ireland and the Irish as an essentialist place and people, given over to a destiny that is inscribed in the past and will be reinscribed in the future. Multiplicity and plurality cannot be recruited to any single-minded notion of essence or identity. He feels that Ireland has been turned into an alien land both by the colonizers and by the various sponsors of the different revival movements. It is this Ireland that he is dreaming of freeing from the clutches of a despicable colonialism and a fake nationalism. 


\section{Repudiating glorification of the past}

In A Portrait Joyce does not comply with the glorification of an ideal past; instead he is craving for a newly imagined and re-imagined future. Stephen says: "Not this. Not at all. I desire to press in my arms the loveliness which has not yet come into the world" (273). [1] "The past is consumed in the present and the present is living only because it brings forth the future" (273). Stephen is seeking the imagined future, not the re-imagined past of Ireland. Joyce dares to differ from Yeats and other nationalists, in this respect. Stephen declares: "I do not fear to be alone or to be spurned for another or to leave whatever I have to leave. And I am not afraid to make a mistake, even a great mistake, a life-long mistake and perhaps as long as eternity too" (269). Stephen always refuses to glorify the past and he is set apart from other characters who revel in valorising the past. Stephen's father who is described by Stephen as "a praiser of his own past" (262) takes delight in replaying his adolescent life in Cork. Emma remembers her childhood that she spent in the company of Stephen. "Certainly she remembers the past. Lynch says all women do. Then she remembers the time of her childhood - and mine if I was ever a child" (273). But Stephen does not like to dwell in the past which he associates with women. "Statues of woman, if Lynch be right, should always be fully draped, one hand of the woman feeling regretfully her own hinder parts" (273).

Stephen is going to make Ireland part of history by making it open to future. Endlessly repeated experience, a reality encountered for the 'millionth time' is going to be made into something that has so far remained 'uncreated'. The kind of repetitions in his Irish life, its monotony, variety and intensity constitute the rhetoric of hell, and as in hell, he can't tolerate the fact that it has to go on forever. So he must escape. His ambition is to 'fly by those nets', 'to watch the flight of birds from the steps of the National Library as auguries of the future' (243-44) and to invoke Daedalus, 'a hawk like man flying sunward above the sea' (183). Seamus Dean points out in his introduction to A Portrait: " $[\mathrm{H}]$ e does not escape from his Ireland: he escapes with it. He brings it into another world. He wants to absolve it from the fate of sameness, the monotony of a repetition that becomes merely farcical" (xxix). Joyce believed that nationalism was nothing other than an extension of the British and the Roman imperialisms despite its apparent antagonism to them. So he could find no alternative to imperialism and nationalism other than an attitude of fierce repudiation. [2]

Young Stephen during his years of formation found himself put under pressure. He heard about him the constant voices of his father and of his masters, urging him to be a gentleman above all things. Yet another voice had bidden him to be true to his country and help to raise up her fallen language and tradition (88). But when he grew up he decided to be different by repudiating both the voices. "He was destined to learn his own wisdom apart from others or to learn the wisdom of others himself wandering among the snares of the world" (175). "He would create proudly out of the freedom and power of his soul, as the great artificer whose name he bore, a living thing, new and soaring and beautiful, impalpable, imperishable"(184). In this quest for the new and the beautiful, he has to abandon the artifice called the nation state and all the decayed systems of education, religion and other institutions of the state. Stephen tells Davin: "This race and this country and this life produced me.... I shall express myself as I am" (220). "My ancestors threw off their language and took another.... They allowed a handful of foreigners to subject them. Do you fancy I am going to pay in my own life and person debts they made? What for?" (220). He ultimately declares his decision: "When the soul of a man is born in this country there are nets flung at it to hold it back from flight. You talk to me of nationality, language, religion. I shall try to fly by those nets" (220). When Davin tells him that a man's country comes first, Stephen asks him: "Do you know what Ireland is? ... Ireland is the old sow that eats her farrow" (220). His sense of unbelongingness is revealed in another passage : "And under the deepened dusk he felt the thoughts and desires of the race to which he belonged flitting like bats, across the dark country lanes, under trees by the edges of streams and near the poolmottled bogs" (259). He also thinks of the Irish as "a race of clodhoppers" (272). When he crossed Stephen's Green once, he remembers the queer pronunciation of one of his Italian lecturers and says that "his countrymen and not mine had invented what Cranly the other night called our religion" (271). He firmly declares his belief: "I will not serve that in which I no longer believe whether it call itself my home, my father land or my church: and I will try to express myself in some mode of life or art as freely as I can, using for my defence the only arms I allow myself to use - silence, exile, and cunning" (268-69). "I may learn in my own life and away from home and friends what the heart is and what it feels" (275). "The country and culture he repudiated was also the country and culture he reimagined. The absence could become a presence. Time and again in his writing Joyce characteristically salutes and bids farewell to the Ireland he had left and to the Ireland he created in his absence from it and its absence from him" (Deane 1990: 53). [3]

\section{Critiquing state- centrism and essentialism}

For Joyce, nationalism is not merely a historic event that stood for political emancipation, but a complex cultural and political process induced by modernization and colonization accompanied by a lot of cultural and social issues. Through the elaborate narrative unravelling of the individual propensity of the protagonist in A Portrait of The Artist as a Young Man, Joyce critiques the racial essentialism and the narrow 
cultural and political constructs created by Irish nationalism. As Joyce believed that nationalism inevitably resulted in a political mechanism, he also stood against state centrism of the Irish nationalist historiography. At the close of the novel, Stephen clarifies his desire to escape from what is politically and socially constructed and to find freedom for himself and for his race beyond the inherited repertoire the past has made available and also beyond the narrow national prospects promised by future. All throughout the novel, Stephen is noted for his refusal to be converted to a character 'individually' and 'nationally' by the powers of imperialism. He did not believe that real freedom is going to dawn on Ireland through the triumph of the kind of nationalism that is taking its course at the time which he believed will surely end up in the establishment of a nation state. The citizens in the modern state are mobilized as members of a larger imagined community and they identify geographic space as a fixed, mutually agreed upon territory with specific borders.

Joyce's distrust for the construct of the nation state gets revealed in a passage in which child Stephen writes down his name in his Geography book. He opens the Geography book to study the lesson; but he cannot learn the names of places in America. Still they are all different places that have those different names. They are all in different countries and the countries are in continents and the continents are in the world and the world is in the universe. He turns to the flyleaf of the Geography book and reads what he has written there: himself, his name and where he is:

Stephen Dedalus

Class of Elements

Clongowes Wood College

Sallins

Country Kildare

Ireland

Europe

The World

The Universe. (12)

Fleming makes an alteration to it:

Stephen Dedalus is my name,

Ireland is my nation.

Clongowes is my dwellingplace

And heaven my expectation. (13)

This attempt, though not appearing to have any serious significations, can be read in the light of his attitude towards the construct of the nation state. It is an attempt to find out the meaning of his positioning specifically, within political and geographical boundaries in the vast infinity of the universe. He wonders: "What was after the universe? Nothing. But was there anything round the universe to show where it stopped before the nothing place began? It could not be a wall but there could be a thin line there all round everything" (13).

The novel can thus be seen as a critique of the modernist notion of the nation states that tend to construct themselves as imagined communities with a national essence, character, and identity, resulting in a value laden hierarchy that writes out or homogenizes 'non-conforming' 'others'. Nations are always eager to establish homogeneity - to bring all kinds of differences into a plane of commonality or to erase differences in order to bring about a cohesive identity. Vincent Cheng in the essay "Joyce, Race and Empire" remarks that the idea of "nation' leads to the discursive reification of a rather arbitrary and homogeneous 'national character' imposed upon a necessarily very heterogeneous collection of different people(s) over a wide expanse of territory. The process which Anderson calls 'imagining the nation' and which Bhabha calls 'writing the nation' writes out (erases) differences and the realities of a pluralistic and culturally diverse 'contact zone' so as to establish an essentialized (but largely imaginary) 'national character'. As a result, Cheng observes that "the nation becomes a totalized version of the universal - particular, an attempt to universalize individual difference to homogenize heterogeneity: nation-formation leads to the imagined / imaginary collectivity which results in essentialisms" (318). [4]

Cheng further points out that in Ireland there were popular investments in an imagined and essentialized national identity. As such a totalizing movement was very much behind the Irish nationalist construction of an Irish / Celtic national character. The leading ninetieth-century Irish authors - up to and including Yeats, Shaw, Synge and Douglas Hyde - tried repeatedly to 'imagine' (both for their subject matter and for their ideal audience) 'communities' which they defined as the Irish nation and race, with all the desired 'national character' and radical uniqueness which each one fantasized. This can be viewed as part of the process which Bhabha called 'writing the nation'. Cheng observes that in such a process, the ambivalence involves a discursive occlusion of the internal cultural differences which exist within any large and heterogeneous contact zone. As Bhabha has observed in The Location of Culture, the barred nation it/self, alienated from its eternal self-generation becomes a liminal form of social representation, a space that is internally marked by cultural difference and the heterogeneous histories of contending peoples, antagonistic authorities, and tense cultural 
locations (212).[5] He observes that the result is essentialized national stereotypes (of both the national Self and of its Others) constantly driven by a nostalgia for pure origins in an 'attempt to hark back to a "true" national past, which is often represented in the reified forms of realism and stereotype' (213).

Thus Joyce identifies the danger of a unisonant and monologic perspective which is blind to the pluralistic and heterogeneous perspective available within a nation. Joyce has expressed this nationalistic xenophobia and chauvinistic myopia through the trope of the one-eyed Cyclops in Ulysses in a brilliant and effective way. The men in the pub can be seen to have the limited, monologic, cycloptic vision of an ethnocentric and xenophobic nationalism. In the novel, Joyce criticizes all forms of Irish nationalism which hark back to a nostalgic pre-colonial rural utopia, and which promulgate a singular racial identity. In Ulysses he makes Leopole and Molly Bloom respectively of Hungarian Jewish and English-Spanish descent. This choice of his central protagonists is radical, in the context of his cultural nationalist project to 'forge the uncreated conscience of [his] race. C.L. Innes has remarked: "James Joyce reacts to the monolithic Celtic identity endorsed by the Gaelic League and the Celtic Revival by foregrounding a Jewish Irishman of Hungarian descent as his central protagonist, and including also Italian and Anglo-Irish characters and an array of European and American references" (162).[6]

Joyce's repudiation of the arbitrary concept of the nation state gets validated through the Daedalus myth which prologues and epilogues the narrative. Daedalus and Icarus always symbolize the urge to escape from the labyrinths of imprisonment which in this fictional context epitomizes the idea of confinement and narrowness of the modern nation state. Thus invoking Daedalus as his father, Stephen is putting on record his resentment of the claustrophobic sensation as well as expressing his insatiable urge for escape out into the infinite scapes beyond the boundaries of a geographically defined nationality as well as the racially defined version of Irish nationalism. Stephen aspires to escape from what is politically and socially constructed. By invoking Daedalus and identifying himself with Icarus, he wants to find freedom for himself and for his race.

In A Portrait, thus Joyce battles against the homogenising agenda of nation and nationalism. He knew that this agenda is going to thwart the multiple / heterogenous façade of the nation. The agenda of converting many- intoone still operates as a threat to the postcolonial nations. He wants to 'decolonize' the concept of the nation state. Anderson begins his book Imagined Communities by acknowledging that "nation-ness is the most universally legitimate value in the political life of our time" (12).[7] There are critics who argue that nations are in some sense 'natural', 'essential', 'substantial' and 'enduring', a primordial element of nature, and intrinsic to the human condition. Joyce would have preferred the pre-historic, pre-modern nations based on ethnic and cultural collectivity rather than on political organization and unity. Thus in A Portrait he takes up a vulnerable position with regard to nationalism which is not a blunt denial of the basic essence of nationalism. On the other hand, he seriously views and weighs the issue in the background of Ireland's cultural complexity and also in the background of the future prospects of the narrow constructs of the nation state. In the essay, "Unmasked Subjects: Identity as Fabrication in Joseph Strick's A Portrait of the Artist as a Young Man and Ulysses", Maria Pramaggiore comments: "Stephen's consciousness is associated virtually with the "I" of Ireland, despite, of course, his repeated pronouncements rejecting the limitations of a national identity. This "I", surely a linguistic pun, signifies Stephen's yearning for a subjectivity freed from constraints of nation, culture, and religion" (63). [8]

Stephen is engaged in a relentless attempt to arrive at a re-imagined future based on a primordial feeling of belonging where there is real horizontal relationship. Based on the link between nation and imagination, Joyce provides a new possibility of imagining a nation outside the grids of the nation state. In $A$ Portrait, he shows how through the recreation of the primordial and the perennial cultural and ethnic propensity of Ireland, such a nation can be forged, and thus the reality of experience can be encountered. It necessitates a freedom of imagination which does not come out of certain "modular" forms already made available by the western modernity. Partha Chatterjee in his Nation and Its Fragments takes up Anderson's notion of 'imagined communities' and redefines it. In Imagined Communities Anderson demonstrated with much subtlety and originality that nations were not the determinate products of given sociological conditions such as language or race or culture or religion. They had been in Europe and every where else in the world, imagined into existence (6). He argued that the historical experience of nationalism in Western Europe, in the Americas and in Russia had supplied for all subsequent nationalisms a set of modular forms from which nationalist elites in Asia and Africa had chosen the ones they liked. But Chatterjee raises objection to it and says that Asian and African nationalisms were different in the sense that they no longer adopted modular forms in shaping their nationalist sentiments or in imagining their communities. Chatterjee says that "the most powerful as well as the most creative results of the nationalist imagination in Asia and Africa are posited not on an identity but rather on a difference with the "modular" forms of the national society propagated by the modern west"(5).[9] 


\section{Identifying the cultural domain}

Joyce clearly knew that Irish nationalism was identical with the modern, modular forms. That is why he took such a different stand in his works on the issue of nationalism and he wanted Irish nationalism to make a 'difference' with the modular forms. He also knew that this difference can be established not through the material / political methods but through the essential resource of cultural identity. Partha Chatterjee observes that "anti colonial nationalism creates its own domain of sovereignty within colonial society well before it begins its political battle with the imperial power. It does this by dividing the world of social institutions and practices into two domains - the material and the spiritual" (6). The material is the "outside" domain of the economy of state-craft, of science and of technology. The spiritual, is an "inner" domain bearing the "essential" marks of cultural identity. While in the outside domain, the western superiority has to be acknowledged, there is a need to preserve the distinctness of one's spiritual culture. It was understood by countries like Asia and Africa, and Chatterjee observes that they declared the domain of the spiritual its sovereign territory and refused to allow the colonial power to intervene in that domain. This is exactly what James Joyce wanted Ireland to do. But Ireland did not care to declare the sovereign territory for the spiritual domain as done by Asia and Africa who were capable of keeping the colonial state out of the "inner" domain of national culture. "If the nation is an imagined community, then this is where it is brought into being. In this its true and essential domain, the nation is already sovereign, even when the state is in the hands of the colonial power" (6). Chatterjee says that the dynamics of this historical project is missed when the story of nationalism begins with the contest for political power. It is this project that Joyce wanted to carry out.

Chatterjee includes language and aesthetics among other commonly recognized elements of cultural identity. He says that language belongs to that inner domain of cultural identity from which the colonial intruder had to be kept out. Language therefore became a zone over which the nation first had to declare its sovereignty and then had to transform in order to make it adequate for the modern world (7). Here, Stephen's attempt to construct an aesthetic form that is national and recognizably different from that of colonizers can be seen as an attempt to establish the inner domain of cultural identity. "The history of nationalism as a political movement tends to focus primarily on its contest with the colonial power in the domain of the state" (9). Partha Chatterjee thus draws a distinction between nationalism as a political movement, which challenges the colonial state and nationalism as a cultural construct, which enables the colonised to posit their difference and autonomy.

\section{The polyphonic perspective}

When Benedict Anderson construed nation not as an inevitable product of sociological factors such as common language, race, religion and history but as an "imagined political community - imagined as both inherently limited and sovereign" (6), he highlighted this link between nation and imagination that existed even earlier. He analysed the ways in which people envisioned nations in a capitalist world system and argued that nation is essentially a discursive formation. Bhabha's nation - narration argument further advanced the role of imagination and narration in the conceptualization of nation. But very often what happens is that nation becomes once again a grand replica of the imperialist domination which marginalizes certain sections of the society. Breaking the autocracy of grand-narratives of nation, Homi K. Bhabha argues that representation of nation could occur only through "double writing" or "dissemination" (202).

Joyce attempts this dissemination by accommodating the marginalized voices. That is why at the end of the novel, Stephen takes up the mission of forging in the smithy of his soul, the uncreated conscience of his race, thereby foregrounding the cultural distinctiveness of the Gaelic by reinstating its polyphonic nature. He believed that Ireland can never own up national purity as it is an amalgam of Celtic and Gaelic elements. The Celtic argument for racial purity and national characteristics was rejected by Joyce and he reminds us that the Celtic race was 'compounded of the old Celtic stock and the Scandinavian, Anglo-Saxon and Norman races. He is trying to detranscendentalise nationalism through a sort of training of the imagination to take the nation out of the grids of such nation states which result in dissemination. Joyce focuses on the role of imagination in the formation of nation as a cultural construct which is capable of establishing its 'difference'. Joyce also wants to capture and celebrate the multiple voices that make the nation. Many voices coming from different locations margins, minorities, diasporas etc. should be accommodated in the fabric of the nation. These voices contest, contradict and complement each other and what results is no cacophony but the essential composite nature of the collectivity called nation. He knew that the homogenizing agenda is going to thwart the multiple / heterogeneous façade of the nation. So even while imagining a nation with a cultural distinctiveness collectively, he is thinking about the need for preserving the racial, cultural and religious distinctiveness individually. His dream nation is not simply a collective social construct, but an individual cultural collectivity.

\section{Conclusion}

Contextualized within the trajectory of nationalism, A Portrait of the Artist as a Young Man can be seen as a cultural text that foregrounds the forging of the 'uncreated'. Joyce is found to stand for a spiritual line 
of nationalism that repudiates valorisation of past and opts for a newly imagined future. Stephen's decision to leave Ireland is not just an escape of the colonized from the colonial confinement. But it is also an escape from the labyrinthine ways of a manipulated nationalism and the modern construct of the nation. This is skilfully presented through the Daedalus myth. A Portrait documents Stephen's struggle against the chauvinistic and monologic perspective of nationalism which tries to establish an imagined community in postcolonial terms. Joyce provides the possibility of imagining a nation outside the grids of the nation state through the recreation of the primordial cultural and ethnic propensity of Ireland. By foregrounding heterogeneity beyond essentiality, he challenges the homogenizing agenda of the nation state and takes up the mission of forging in the smithy of his soul, the uncreated conscience of his race.

\section{References}

[1]. Joyce, James. A Portrait of the Artist as a Young Man. London: Penguin, 2000. Print.

[2]. Deane, Seamus. Introduction. A Portrait of the Artist as a Young Man By James Joyce. London: Penguin, 2000. Print.

[3]. "Joyce the Irishman". The Cambridge Companion to James Joyce. Ed. Derek Attridge. Cambridge: CUP, 1999. 31-53. Print.

[4]. Cheng, Vincent J. "Joyce, Race and Empire." Post-Colonial Theory and English Literature: A Reader. Ed. Peter Childs. Edinburgh: Edinburgh University Press, 1999. 315-28. Print

[5]. Bhabha, Homi K. The Location of Culture. London: Routledge, 2004. Print

[6]. Innes, C L. The Cambridge Introduction to Postcolonianl Literatures in English. New Delhi: CUP, 2007. Print.

[7]. Anderson, Benedict. Imagined Communities:Reflections on the Origin and Spread of Nationalism. London: Verso, 1983. Print.

[8]. Pramaggiore, Maria. "Unmasked Subjects: Identity as Fabrication in Joseph Strick's A Portrait of the Artist as a Young Man and Ulysses". James Joyce and the Fabrication of an Irish Identity. Ed. Michael Patrick Gillespie. Amsterdam-Atlanta: Rodopi, 2001. European Joyce Studies 2. 52-70. Print.

[9]. Chatterjee, Partha. The Nation and Its Fragments: Colonial and Post Colonial Histories. New Delhi: OUP, 1994. Print. 